DOI: https://doi.org/10.24113/ijellh.v9i1.10886

\title{
Subverting Gender in Laxmi Raj Sharma’s 'Intriguing Women’
}

\author{
Kaustubh Mishra \\ MPhil Scholar \\ Department of English \\ University of Delhi \\ Delhi, India \\ kaustubhmishra7@gmail.com
}

\begin{abstract}
This paper close reads the short story collection Intriguing Women by Laxmi Raj Sharma to explicate upon the theme of ideological subversion within it. Sharma deploys his female characters as agents of destabilisation that assert their own identity and thu s question the dominant social constructs. In doing this, these characters raise questions about the ruling ideology and its established norms of behavior, selfhood and performance. While Sharma's usage of motifs and structural forms makes the stories works of art, the actions of his characters make them didactic and pushes the readers towards questioning some of their fundamental assumptions.
\end{abstract}

Keywords: Feminism, Ideology, Subversion, Women, Gender-Roles

Societies everywhere operate by keeping their members under strict control. This control is all pervasive - it extends to all aspects of the individual - the public: dictating how they may carry themselves, who they ought to be friends with, as well as the personal: dictating how they may behave, dress, eat, sleep, form relationships; whom they ought to and ought not to - marry etc. This control is enacted and enforced in many ways, both overt 
and covert. While there are institutions such as the family, legislative bodies, courts, police that seek to punish those who deviate from the lawful path; control also works in much more subtle ways.

One of the most effective ways in which societies control their constituents is psychological. Foucault in his 1975 book Discipline and Punish borrowed the idea of the Panopticon, a conceptual prison designed by Jeremy Bentham, to describe how modern societies use surveillance to effect obedience and conformity. Discipline is an apparatus of power. By making its members both the objects as well as the enforcers of disciplinary norms, societies de-center control and make it more efficient and all pervasive. Elaborating on the analogy to the Panopticon, he said that in a society people take upon themselves the onus of disciplining themselves, as they are aware of being under the constant scrutiny of their compatriots, even as they work as foot soldiers of societal surveillance. Thus, people become both inmates, as well as the sentry in the central tower - so to speak.

However, Foucault fails to account for the gendered nature of subjectivity and how men and women comprehend the world differently. Catherine Mackinnon speaks of the lack a female consciousness, postulating that the nature of the dominant consciousness is undoubtedly male, in which female ways of seeing are not given due representation. The world, she says, is perceived, interpreted and constructed through a consciousness that is male, heterosexual and sexist.

Women are looked at not as they want to be seen but as the male gaze wants to see them. This consciousness is so pervasive that it is imbibed by women themselves, and they start to think of themselves through this male-made, heterosexual lens. Women are thus always defined in terms of - in opposition to - the male sexuality. "Contemporary industrial society's version of her is docile, soft, passive, nurturing, vulnerable, weak, narcissistic, 
childlike, incompetent, masochistic, and domestic, made for child care, home care, and husband care" (MacKinnon 530).

Most of these aspects, if scrutinized carefully will be found constructed so as to be a vehicle for the expression of the male sexual desire; turning women into passive receptacles to be acted upon by the male sexuality. Thus, "vulnerability means the appearance/reality of easy sexual access, passivity means receptivity and disabled resistance, enforced by trained physical weakness; softness means pregnability by something hard. Incompetence seeks help as vulnerability seeks shelter, inviting the embrace that becomes the invasion" (MacKinnon 530).

Sandra Lee Bartky further develops upon Foucault's ideas and analyses how they apply to women. Bartky's critique is that Foucault fails to account for how surveillance works differently for men and women. Women, she says, have an experience of societal control that is both different and more stringent than the male experience. According to her, "Foucault treats the body throughout as if it were one, as if the bodily experiences of men and women did not differ and as if men and women bore the same relationship to the characteristic institutions on modern life" (Bartky 27). She accuses Foucault of being "blind to those disciplines that produce a modality of embodiment that is peculiarly feminine" (Bartky 27). This is a completely valid point. Many societies hold men and women up to different standards and have different expectations of them. It follows that surveillance and control must work for both of them in different ways, too. This is especially true of patriarchal societies, where women have to operate under a heterosexual male consciousness that is the dominant ideology. Indian society, for example, while known for its communal and collective forms of living exerts a massive influence on the life of its women. An Indian woman has to be conscious of what she wears, how she speaks, who she befriends at all 
times. The slightest transgression against the set norms of society - whether real or perceived - can have serious consequences.

But across time and cultures, women have often hit back - so to speak. Even as surveillance and control mechanisms change and adapt to modern ways of seeing and regulating, women have been just as active at dodging and subverting it. This quiet - and in some instances, not so quiet - subversion of patriarchy-defined norms of femininity is one of the central themes of Laxmi Raj Sharma's collection of twenty three short stories aptly titled Intriguing Women.

The stories portray women - mostly Indian - who come from diverse backgrounds: working class, middle class, nouveau-riche, Hindus, Muslims, Christians etcetera. Yet, the common thread that binds these stories together is the ways in which these women resist heterosexual, male-made ideas of femininity and shape their lives in complete disregard to society. This paper attempts to examine Laxmi Raj Sharma's stories in light of these findings and determine the nature of their sexual politics.

The collection starts off with "Contemporary Women" the story of Anwar Sheikh, a young Indian Muslim man who is in London for a few months. He happens to be staying with a family that has two young sisters his age. Sheila is the more conservative of the two and has a particular dislike for men. She serves as the disciplinarian - checking and correcting her sister as she sees fit. The other sister Julianne is the discipline-breaker, and is not afraid to put her body on display for her sister to paint. She tells her sister, "Contemporary women don't live without clothes. Only clothes cannot and should not conceal them. If men can uncover without consciousness, so can we. We should wear clothes when we feel like wearing them and tear them off when they seem cumbersome" (Sharma 7). The question of why being topless is a taboo only for men and not for women has been a matter of intense debate in contemporary society. Feminist thinkers see this as yet another example of a heterosexual 
male consciousness, where the breasts are sexualized while the male chest isn't. Living up to the story's title, Julianne proves to be a woman who is not afraid to challenge diktats of a patriarchal society. She is not afraid to speak up when she feels like and takes what she wants, as we see when she asks Anwar for a kiss - they make out, but Julianne doesn't get emotionally attached to him. She has the capability of keeping love and lust separate - when asked her opinion of Anwar by her sister, she replies: "I can’t take him seriously" (Sharma $11)$.

The next story with an unconventional female character is "Bonding": the story of Suparna, a homosexual woman who is married off to Himanshu against her wishes. Suparna is not just a lesbian; she also shows a vicious dislike for the male species. She is a radical feminist, who considers her husband "like any bloody man". Men, she says, "appear very innocent and then one day they make you pregnant, with nowhere to go for help" (Sharma 125). Suparna had been in a romantic relationship with one of her college friends, Pallavi. She intended to marry her, however owing to emotional blackmail from her parents that plan couldn't come to fruition. She vents her frustration on her husband Himanshu, throwing away all norms of newly-wed behavior. Throughout the story, we see her bossing her husband around, in a shocking, even comical reversal of traditional gender roles.

Cast in opposition to the Himanshu-Suparna-Pallavi trio, are Himanshu's wife Haider, his wife Saba and her divorced sister Shama. The latter trio serves as a foil to the former while Suparna can't wait to get out of her marriage, Saba is threatened by her sister's proximity to her husband and is afraid he might fall for her. Here we see, as is tradition, two women defining themselves through their relations to their male relatives. As the two trios get to know each other, an affinity starts to develop between Suparna and Shama. While Sharma does not give us any reasons to believe that their relationship is of a romantic nature, there is definitely a strong sense of loyalty, where each woman finds solace in the company of the 
other after spurning men. In the end, Suparna decides to leave her husband for good and moves with Shama to Delhi, planning on starting a new life with her.

"Bonding" is also ripe with accounts of a sisterhood of women, facing common struggles and standing in solidarity with each other. Sisterhood is vital for liberation of women, because it leads to destruction of internalized sexism and causes women to start questioning their ways of thinking. Under patriarchal indoctrination, women see themselves as always and only in competition with one another for patriarchal approval (Hooks 14). From Pallavi's account of her college days with Suparna where she protected her from male aggression to Suparna and Shama's desire to leave their lives in patriarchal setups and live independently, we see this sisterhood at work, leading to the emergence of multiple feminist consciousnesses in the story. While it could definitely be argued that Suparna is too radical and narcissistic, and does injustice to her husband, the fact that she is willing to break convention does make her actions worth commendation.

A common occurrence throughout the collection, seen in multiple stories is men confused and baffled when faced with an unconventional female sexuality. In "Bonding", for example, the husband reacts with disbelief and frustration at the idea of his wife being a lesbian. He is less hurt by the fact that she did not divulge this fact before marriage and more appalled at the fact of her being one. He is invested in the existing social order to an extent that any subversion of it leads to discomfort and disbelief at the most primal level. The notions of femininity and masculinity do more than assist in the construction of personal identities, "they are critical elements in our informal social ontology. This may account to some degree for the otherwise puzzling phenomenon of homophobia and for the revulsion felt by many at the sight of female bodybuilders; neither the homosexual nor the muscular woman can be assimilated easily into the categories that structure everyday life" (Bartky 39). These emotions of confusion and revulsion are recurring motifs throughout the stories, a 
symptom of a patriarchal society's confusion towards a woman they can neither define nor control.

Although many stories portray acts of infidelity, disloyalty and even bodily harm, the vitality of Sharma's stories lie in the fact that very rarely do we see such acts being valorized or being presented as a force for good. Despite his representation of some very unconventional situations - and a very visible bias towards the fairer sex - Sharma never allows this zeal to get the better of him, always revealing a strong moral sense within his consciousness. Licentiousness, while momentarily may seem to be rewarding, ultimately results in long lasting damage. Take for instance, the story "A French Bite". This story, hard hitting in its depiction of human nature and the fate of those who choose to live unnatural lifestyles, is a tale of a wife who has grown bored with her husband. The husband, Om, is a man who believes in living a simple life, and spends most of his time contemplating the complexities of the world. The wife, Shalini, a polar opposite, believes in living a hedonistic life even at the expense of morality. She becomes acquainted with a French man named Claude living in the city, and invites him to her home. The man soon strikes up a cordial relationship with the husband, and visits them often on the pretext of discussing philosophy with the husband. Soon, things turn steamy between the wife and the Frenchman and they have an affair. The Frenchman keeps up appearances with the husband, visiting them often and sometimes even inviting Om to his apartment under the pretext of discussing philosophy with him while having an affair with wife behind his back.

The ploy ends soon enough, when the police raid his apartment and discover video recordings of him and Shalini in bed. It turns out Claude is in the porn business, and secretly records women while having sex with them. The policemen play the videos right in front of Om, and his world comes crumbling down about him when he sees his wife in bed with the other man. The story ends with Om's musings upon the whole affair; wherein he comes to the 
conclusion that women require a disciplinary authority and they tend to stray from the path of righteousness in the absence of one. While the ending may be sexist and guilty of generalizing to the point of offence, a closer look at the story reveals the authorial intention behind the character of Shalini who, "had heard about feminism and misunderstood it like much else in her life" (Sharma 91). "The French Bite" is what happens when hedonism takes over under the disguise of lofty ideals of liberty and free will, and morality is consigned to the dustbin as an archaic, "sexist", good-for-nothing construct.

A similar moral impulse can be located in many other stories. One notable example would be the story "Bohemian". The story of Supriya and Niloy - a newly married couple who decide to make their marriage into an open relationship; "Bohemian" is an example of how human nature is essentially unchanging, and no amount of theory is going to alter that. While the arrangement works out well initially, jealousy sets in when Niloy finds his wife in a relationship with Pradeep, a close friend of his. Insecurity over sexual prowess and inability to find a woman for himself eventually manifests itself physically, leading to a stroke that leaves him paralysed. Almost ironically, a man who sought to seek independence and freedom in an open marriage is reduced to a bedridden, immobile thing and must depend on Supriya and Pradeep for even the most basic tasks. His condition gives his wife and the friend more freedom to continue their escapades which he must overhear while lying in the room next door. The agony eventually overpowers Niloy, leading to his death.

Intriguing Women is definitely a complex work, filled with subtle nuances, many of which might not be obvious at a first reading. At first sight, the text might appear unabashedly feminist, almost sycophantic towards women. Even the acknowledgment says:

I am grateful to womankind for overpowering my mind.

A mother's role goes beyond words. 
Sisters speak through younger brothers eternally.

Beauty attracts, impacts; sets thinking.

Ugly men just watch, admire and philosophise (Sharma iv).

However, a closer reading of the text shall reveal that this is not the case. No doubt, Sharma takes a welcome and much-needed stance in so far as acknowledging women's needs, desires and agency. He tells stories of women who are bold and not afraid of taking what they want, sometimes with force. He tells stories of women who defy all forms of social control and express their sexuality while the world looks on helplessly, of women who do not tolerate marital discord meekly and serve their husbands divorce papers within a year of marriage. Yet he manages to keep his head on his shoulders while dealing with the issue of personal liberty versus collective good - a breath of fresh air in these times. He makes it clear that freedom ought not to translate into stubborn defiance of all tradition. Change for the sake of change is a flawed notion that can often do more harm than good. Intriguing Women makes a much needed intervention in current social discourse, managing to both advocate for feminism and warn against its excesses, a miraculous feat by all standards. 


\section{Works Cited}

Bartky, Sandra Lee. "Foucault, Femininity and the Modernization of Patriarchal Power." Feminism and Foucault: Reflections on Resistance, eds. Irene Diamond and Lee Quinby, Northeastern UP, 1988. Print.

Hooks, Bell. Feminism is for Everybody: Passionate Politics. South End P. 2000. Print.

MacKinnon, Catherine. "Feminism, Marxism, Method, and the State: An Agenda for Theory." Signs: Journal of Women in Culture and Society, Vol. 7, No. 3, 1982, pp. 515-544, www.jstor.org/stable/3173853. Accessed 10 March 2017. Web.

Sharma, Laxmi Raj. Intriguing Women. The Paris Press, 2016. Print. 